\title{
Hubungan antara Kompensasi dan Sikap Proaktif dengan Motivasi Kerja Karyawan pada Industri Perhotelan
}

\author{
Morissan \\ Universitas Mercu Buana, Jakarta \\ morissan@yahoo.com
}

\begin{abstract}
Motivation of employees will be a determining factor for the success of the company, especially in in the hotel industry, where contact between employees and customers is relatively intensive. The quality of work will decrease if employees unsatisfied and it can be felt directly by guests. One of important variables that can affect working motivation is compensation. Good compensation will encourage employees to work well and more productive. Working motivation is also closely related to proactive behavior. This study aims to determine the relationship between employees perceptions of compensation and proactive behavior to working motivation. The respondents are 700 employees working in 37 stars and non-star hotels throughout Indonesia. The result shows that there is a relationship between employees perceptions of compensation and proactive behavior to working motivation.
\end{abstract}

Keywords: Compensation, Hotel, Human Resources. Motivation, Proactive.

\section{PENDAHULUAN}

Pengelolaan sumber daya manusia di tempat kerja merupakan komponen penting dalam proses manajemen. Karyawan memiliki peran yang sangat penting di dalam organisasi, dan elemen manusia dan organisasi harus berjalan bersama untuk dapat mencapai tujuan organisasi. Penting bagi perusahaan untuk membuat karyawan mereka termotivasi. Dalam karya mereka, Minner et al. (1995) menguraikan bahwa, motivasi terdiri dari tiga elemen yang saling berinteraksi dan saling tergantung, yaitu kebutuhan, dorongan, dan insentif. Kompensasi telah diakui sebagai motivator utama bagi karyawan serta instrumen dan pengeluaran penting bagi organisasi.

Pada perusahaan yang bergerak di bidang jasa perhotelan, dimana kontak antara karyawan dengan tamu relatif intensif, motivasi kerja karyawan akan menjadi faktor penentu keberhasilan perusahaan. Karyawan yang tidak puas menyebabkan kualitas pekerjaan menurun dan hal dapat dirasakan langsung oleh tamu. Tamu yang kecewa merupakan ancaman bagi hotel karena mereka akan pindah kepada pesaing. Untuk itu motivasi kerja karyawan harus senantiasa dipelihara agar keberhasilan perusahaan dalam mencapai tujuannya dapat dicapai.

Dewasa ini pertumbuhan hotel di Indonesia begitu pesat terbukti dengan jumlah kamar hotel di Indonesia yang besar. Hingga tahun 2017, jumlah hotel berbintang mencapai 2.300 hotel dengan Rp290.000 kamar. Sementara untuk non-bintang jumlahnya mencapai 16.000 dengan sekitar Rp285.000 kamar di seluruh Indonesia. Perkembangan industri hotel ini diprediksi akan terus berlanjut. Pada tahun 2018 akan ada sekitar 55.000 tambahan kamar baru (Soekamdani, 2017). Namun perkembangan 
pesat industri perhotelan ini tidak diimbangi dengan sumber daya manusia yang memadai. Kurangnya sumber daya manusia yang profesional di sektor ini menjadi masalah tersendiri.

Penyerapan tenaga kerja di sektor hotel dan restauran dewasa ini tergolong baik namun tidak mudah mencari tenaga ahli yang terbaik. Pertumbuhan industri yang cepat tidak diimbangi kesiapan kualitas SDM. Menurut Asosiasi Hotel Jakarta (Jakarta Hotel Association). kualitas SDM berkontribusi penting dalam penentuan tingkat harga (rate) hotel hingga jumlah pengeluaran tamu hotel. Makin baik SDM, semakin baik pula prestise hotelnya. Tamu pun akan rela keluar uang lebih banyak. Kualitas dan sertifikasi SDM pun jadi hal penting (Nayoan, 2017). Namun demikian kekurangan pengetahuan dan keterampilan yang diperlukan masih dapat diimbangi dengan kepribadian positif dan sikap yang benar yang dimiliki para karyawan sehingga mereka tetap berusaha untuk melakukan yang terbaik dalam melaksanakan pekerjaan dan mengejar karir secara positif (Ling, 2017). Faktor utama dalam mencapai kesuksesan karir adalah bahwa karyawan harus memiliki sifat-sifat positif, seperti perilaku karir proaktif. Dengan kata lain, kualitas SDM yang tidak ideal tentunya masih bisa diatasi jika SDM memiliki motivasi tinggi dalam bekerja. Karena alasan ini, menjaga motivasi karyawan hotel menjadi faktor penting bagi pengelola dan pemilik hotel.

Menurut Kertonegoro (1997) motivasi adalah kemauan untuk melakukan tingkat upaya yang tinggi kearah tujuan organisasi yang dipengaruhi oleh kemampuan untuk melakukan dan memenuhi kebutuhan individual. Unsur upaya mencakup intensitas (orang berusaha keras) maupun kualitas (upaya yang konsistensi dengan tujuan organisasi). Selain motivasi dari karyawan, perhatian dari manajemen juga diperlukan untuk bisa menjaga, menumbuhkan, dan mengarahkan motivasi kerja tersebut demi tercapainya tujuan perusahaan.

Karyawan disebut memiliki motivasi kerja yang baik jika mereka memiliki semangat dan keinginan untuk menyelesaikan pekerjaannya dengan baik, mempunyai kehendak untuk berhasil dalam tugas dan memiliki keinginan untuk maju dan berkembang. Sebaliknya karyawan yang tidak memiliki motivasi adalah mereka yang bermalas-malasan, menyelesaikan pekerjaan sekehendak hatinya, tidak mempunyai ambisi untuk maju dan selalu menyalahkan kondisi dan lingkungan di tempat dimana mereka bekerja.

Menurut Gibson (1997) kompensasi merupakan salah satu variabel penting yang dapat mempengaruhi motivasi kerja karyawan sehingga perusahaan harus menerapkan suatu sistem kompensasi yang memuaskan dengan mempertimbangkan kemampuan organisasi. Istilah kompensasi sendiri dapat diartikan sebagai segala bentuk financial return, jasa-jasa berwujud, dan tunjangan-tunjangan yang diterima karyawan sebagai bagian dari hubungan antara karyawan dan perusahaan. Dalam hal ini kompensasi merupakan suatu extrinsic reward yang berbentuk imbalan moneter seperti gaji, status, promosi, pembagian keuntungan, dan bonus. Sedangkan suatu intrinsic reward memiliki bentuk pengakuan, pekerjaan yang menarik, partisipasi dalam pengambilan keputusan, dan kesempatan kerja yang lebih menantang.

Banyak perusahaan perhotelan dewasa ini yang bersikap proaktif yakni dengan mendatangi langsung relasi dan calon tamu. Tentunya bukan hanya pihak manajemen saja yang bersikap proaktif tetapi juga para karyawannya. Sikap proaktif diduga kuat sebagai faktor yang mempengaruhi karyawan agar termotivasi dalam bekerja. Dalam hal ini, sejauh mana karyawan tersebut merasa dirinya mempunyai kebebasan untuk mengerjakan tugas dan tanggung jawab atas tugas tersebut. Efektifitas kerja karyawan berhubungan erat dengan motivasi kerja, dan motivasi kerja berkaitan erat dengan persepsi karyawan terhadap kompensasi dan sikap proaktifnya.

Penelitian ini bertujuan untuk mengetahui hubungan antara persepsi karyawan terhadap kompensasi dan sikap 
proaktif dengan motivasi kerja pada perusahaan yang bergerak di bidang jasa perhotelan.

\section{Hubungan Kompensasi dan Sikap Proaktif dengan Motivasi Kerja}

Dalam studi mengenai hubungan antara kepuasan kerja dengan kompensasi dan motivasi kerja, Ghazanfar et.al. (2011) menemukan bahwa kepuasan terhadap kompensasi yang diterima dapat menjadi faktor motivasi kerja, sementara bayaran fleksibel (flexible pay) bukanlah menjadi faktor yang memotivasi dalam pekerjaan dan tunjangan (benefit) tidak memiliki dampak yang signifikan terhadap motivasi kerja.

Mensah dan Tawiah (2016) dalam studi mereka tentang motivasi karyawan dan kinerja kerja dengan melakukan studi banding beberapa perusahaan pertambangan di Ghana menemukan bahwa manajemen harus memastikan bahwa karyawan termotivasi dengan baik agar mereka tidak melakukan pemogokan dan kerusuhan industri yang mempengaruhi kinerja mereka. Selain itu, karyawan harus mematuhi peraturan kesehatan dan keselamatan karena industri pertambangan berkontribusi besar pada Produk Domestik Bruto (PDB) negara tersebut.

Studi oleh Ghafari et. Al. (2017) menunjukkan bahwa faktor motivasi yang paling signifikan untuk mendukung kinerja pekerjaan karyawan adalah tanggung jawab, sedangkan tunjangan penghasilan adalah faktor signifikan kedua. Jehanzeb et.al (2012) menemukan bahwa tingkat penghargaan, motivasi dan kepuasan kerja karyawan memiliki hubungan yang kuat di sektor perbankan Arab Saudi. Hasil penelitian menunjukkan bahwa karyawan di sektor perbankan lebih mementingkan imbalan ekonomi atau keuangan. Jadi, jika imbalan ditingkatkan, maka motivasi kerja karyawan yang bekerja pada bank publik dan swasta juga meningkat.

Peretomode (1991) merekomendasikan bahwa semakin besar prestise pekerjaan, semakin tinggi kepuasan kerja. Bakan \& Buyukbese (2013) menunjukkan hubungan yang signifikan antara tingkat pendapatan karyawan dan kepuasan kerja karyawan. Namun, data yang diperoleh tidak memberikan gambaran apapun tentang arah kausalitas yang terjadi. Arefin et.al. (2015) menemukan bahwa organisasi yang menerapkan sistem kerja berkinerja tinggi, dapat merangsang motivasi karyawan dengan cara memberdayakan mereka. Studi mereka mengungkapkan bahwa pemberdayaan psikologis memediasi hubungan antara persepsi karyawan terhadap sistem kerja berkinerja tinggi dan perilaku proaktif karyawan.

Ling et.al. (2017) menunjukkan terjadinya efek mediasi parsial pada perilaku proaktif dalam hubungan antara kualitas pekerjaan (quality of work life) dan kesuksesan karir. Ling menemukan bahwa kualitas kerja dapat secara positif mempengaruhi kesuksesan karir di kalangan akademisi. Jika mereka memiliki perilaku proaktif, mereka akan bersemangat untuk mencapai tingkat keberhasilan karir yang lebih tinggi.

\section{Motivasi Kerja}

Gibson (1997) mengemukakan bahwa motivasi kerja adalah dorongan yang timbul dari dalam diri yang menggerakkan dan mengarahkan perilaku. Jadi motivasi merupakan sikap seseorang terhadap tugastugasnya yang mengarah pada kepuasan kerja. Proses timbulnya motivasi umumnya diawali dengan munculnya suatu kebutuhan yang belum terpenuhi, dan hal ini menyebabkan ketidakseimbangan antara fisik dan psikologis dalam diri seseorang. Karena alasan ini, motivasi juga disebut sebagai kebutuhan, desakan (urge), keinginan (wish), dan dorongan (drive).

Skinner mengemukakan teori penguatan (reinforcement theory) yang menyatakan bahwa perilaku ditentukan oleh (atau merupakan fungsi dari) konsekuensinya. Bila konsekuensinya menyenangkan, seperti mendapat pujian, promosi, imbalan, maka suatu perilaku akan diulang atau diperkuat. Bila konsekuensinya tidak menyenangkan, seperti mendapat celaan, peringatan, 
hukuman, maka suatu perilaku tidak akan diulangi. Bila manajer ingin memberi motivasi karyawannya, maka harus memperkuat perilaku yang diinginkan melalui konsekuensi imbalan, dan memperlemah perilaku yang tidak diinginkan melalui hukuman.

Selain itu, motivasi kerja juga ditentukan oleh motivatornya yang merupakan mesin penggerak motivasi tenaga kerja yang memengaruhi perilaku individu tenaga kerja yang bersangkutan. Herzberg (1966, 1964) mengemukakan unsur-unsur penggerak motivasi yaitu: prestasi (achievement), penghargaan (recognition), pekerjaan itu sendiri (the work itself) dan pengembangan (advancement). Seseorang yang memiliki keinginan berprestasi sebagai suatu "kebutuhan" atau needs dapat mendorongnya untuk mencapai sasaran. Mc Clelland menyatakan bahwa tingkat "needs of achievement" yang menjadi naluri kedua (second nature), merupakan kunci keberhasilan seseorang.

Pengakuan (recognition) atas suatu prestasi yang telah dicapai oleh seseorang akan menjadi motivator kuat untuk bekerja. Pengakuan atas suatu prestasi, akan memberikan kepuasan batin yang lebih tinggi dari pada penghargaan dalam bentuk materi atau hadiah. Penghargaan atas pengakuan dalam bentuk piagam atau medali, dapat menjadi motivator yang lebih kuat dibandingkan dengan hadiah berupa barang atau bonus/uang. Setiap pekerjaan memiliki tantangannya sendiri yang sering kali menjadi motivator kuat bagi karyawan untuk mengatasinya. Suatu sasaran yang tidak menantang atau mudah dicapai biasanya tidak mampu menjadi motivator, bahkan cenderung untuk menjadi kegiatan rutin. Tantangan demi tantangan biasanya akan menumbuhkan kegairahan untuk mengatasinya. Terakhir, pengembangan (advancement) kemampuan seseorang baik dari pengalaman kerja atau kesempatan untuk maju dapat menjadi motivator kuat bagi tenaga kerja untuk bekerja lebih giat atau lebih bergairah. Apalagi jika pengembangan perusahaan selalu dikaitkan dengan prestasi atau produktivitas tenaga kerja.

\section{Kompensasi}

Menurut Martoyo (1994) kompensasi dapat didefinisikan sebagai pengaturan keseluruhan pemberian balas jasa bagi employer maupun employes baik secara langsung berupa uang maupun tidak langsung yang tidak berbentuk uang. Menurut Hasibuan (1990) kompensasi adalah semua pendapatan yang berbentuk uang atau barang, baik secara langsung maupun tidak langsung yang diterima karyawan sebagai imbalan atas jasa yang diberikan kepada perusahaan. Sedangkan Saydam (1996) mengatakan kompensasi adalah balas jasa (reward) perusahaan terhadap pengorbanan waktu, tenaga dan pikiran yang telah diberikan karyawan kepada perusahaan.

Berdasarkan beberapa definisi tersebut dapat ditarik kesimpulan bahwa kompensasi meliputi unsur-unsur yaitu: 1) Kompensasi merupakan balas jasa yang diberikan karyawan dan cenderung dibayarkan secara tetap; 2) Kompensasi merupakan dorongan utama seseorang menjadi karyawan dan besar pengaruhnya terhadap semangat dan kegairahan kerja; 3) Kompensasi mempunyai efek yang positif, maka minimal jumlah yang dibutuhkan haruslah dapat memenuhi kebutuhan minimal; 4) Kompensasi harus mampu meningkatkan kegairahan kerja, sehingga efektifitas dan efisiensi karyawan dapat dipertahankan dan ditingkatkan.Untuk dapat menimbulkan semangat kerja, maka dalam menetapkan jumlah kompensasi harus selalu bersifat dinamis.

Menurut Martoyo (1994) kompensasi memiliki fungsi untuk mengalokasikan sumber daya manusia secara produktif. Kompensasi yang baik kepada karyawan yang berprestasi akan mendorong mereka bekerja dengan baik dan ke arah pekerjaan yang lebih produktif. Kompensasi yang tinggi kepada karyawan mengandung implikasi bahwa organisasi akan menggunakan tenaga karyawan tersebut dengan seefisien dan seefektif mungkin, disinilah produktivitas karyawan sangat menentukan. Sebagai akibat alokasi dan penggunaan sumber daya manusia 
secara efisien dan efektif tersebut maka diharapkan akan membantu stabilitas organisasi dan mendorong pertumbuhan ekonomi secara keseluruhan.

Faktor-faktor yang memengaruhi kompensasi mencakup: 1) Kebenaran dan keadilan. Hal ini berarti pemberian kompensasi kepada masing-masing karyawan harus sesuai dengan kemampuan, kecakapan, pendidikan dan jasa yang telah ditunjukan kepada organisasi; 2) Dana organisasi. Kemampuan organisasi untuk dapat melaksanakan kompensasi baik berupa finansial maupun non finansial amat tergantung kepada dana yang terhimpun untuk keperluan tersebut; 3) Serikat pekerja juga mempengaruhi penetapan kompensasi dalam organisasi dan merupakan "simbol kekuatan" karyawan dalam menuntut perbaikan nasib; 4) Produktivitas kerja. Faktor produktivitas memengaruhi penilaian atas prestasi kerja karyawan; 5) Biaya hidup. Penyesuaian besarnya kompensasi, terutama gaji atau upah, dengan biaya hidup karyawan beserta keluarganya. Tetapi cukup sulit dalam pelaksanaannya, karena biaya hidup seseorang relatif sifatnya, 6) Pemerintah. Pemerintah ikut andil juga dalam menentukan upah minimum ataupun jumlah jam kerja karyawan.

\section{Perilaku Proaktif}

Bateman dan Crant (1993) menggambarkan perilaku proaktif sebagai individu yang menunjukkan kecenderungan yang stabil untuk mengambil inisiatif sendiri yang berupaya untuk memengaruhi dan mengubah lingkungan kerjanya. Individu proaktif memulai perubahan dari pada menerima secara pasif dan beradaptasi dengan perubahan yang dilakukan. Mereka menantang kesulitan yang dihadapi dan mencari cara untuk mengubah hambatan tersebut menjadi peluang berguna yang dapat mempersiapkan mereka untuk menjadi lebih sukses dalam karir mereka. Penelitian sebelumnya yang dilakukan oleh Barnett dan Bradley (2007) menunjukkan bahwa perilaku proaktif memediasi hubungan antara dukungan organisasi dan kesuksesan karir.
Dengan demikian, perilaku proaktif dapat berkontribusi secara signifikan dalam memediasi hubungan antara kualitas kehidupan kerja dan kesuksesan karir.

Menurut Pedler (1997), bersikap proaktif adalah kecenderungan menanggapi peristiwa dengan maksud tertentu. Para karyawan yang proaktif memiliki beberapa maksud dan tujuan yang ingin dicapai, bukan sekadar menanggapi tujuan. Mereka memang tidak bisa merencanakan segalanya dengan hatihati sejak awal, tetapi ketika membuat semacam tanggapan, karyawan yang proaktif dapat mempertimbangkannya dalam jangka panjang. Karyawan yang sukses mampu memberikan tanggapan segera dikaitkan dengan maksud atau tujuan keseluruhan dan jangka panjang, sedangkan karyawan yang kurang sukses memberikan respon terhadap tekanan yang tiba-tiba dengan cara yang relatif tidak kritis atau kurang pertimbangan. Kategori kemampuan ini mencakup kualitas antara lain seperti: melihat pekerjaan secara lebih mendalam, berdedikasi dan bertanggungjawab, memiliki "rasa" atas misi, dan mengambil alih tanggungjawab untuk sesuatu yang terjadi dari pada menghindari dengan melepaskan tanggungjawab kepada orang lain.

Menurut Covey (1998), manusia proaktif berarti bertanggungjawab terhadap dirinya sendiri karena perilaku individu adalah fungsi dari keputusan individu sendiri. Individu mempunyai tanggungjawab untuk membuat segala sesuatunya terjadi. Manusia sebagai individu yang proaktif selalu berusaha keras secara tepat dan arah tujuannya adalah konsepsi yang mempersatukan kehidupan individu. Syarat utamanya adalah individu harus memiliki suatu penetapan tujuan yang harus diperjuangkan. Asumsi dasar proaktif terletak pada sifat dasar manusia yang bergerak kearah penyatuan kehidupan yang relatif. Manusia hidup di dunia untuk tujuan masa depan, ambisi kehidupan, dan usaha keras yang dihasilkan dari dalam dirinya sendiri. Victor Frankl adalah salah satu dari banyak orang yang mampu mengembangkan kebebasan pribadi dalam keadaan sulit untuk mengangkat dan mengilhami orang lain. 
Dalam menemukan prinsip dasar sifat manusia, Frankl (dalam Covey, 1998) menggambarkan sebuah peta diri yang akurat dan dari mana ia mulai mengembangkan kebiasaan pertama yang paling mendasar dari manusia yang paling efektif pada lingkungan apapun.

Walaupun kata proaktif lazim ditemukan pada literatur manajemen, namun arti kata ini lebih dari sekedar mengambil inisiatif. Kata ini berarti bahwa karyawan bertanggungjawab atas hidupnya sendiri. Perilaku karyawan adalah fungsi dari keputusannya, dan bukan kondisi yang ada. Individu dapat menomerduakan perasaan serta mempunyai inisiatif dan tanggungjawab. Dengan demikian dapat disimpulkan bahwa karyawan yang proaktif tetap dipengaruhi stimulus dari luar, baik secara fisik, sosial, atau psikologis. Namun respon mereka terhadap stimulus tersebut, sadar atau tidak sadar, didasarkan pada pilihan atau respons yang didasari oleh nilai-nilai tertentu yang dianutnya seperti dedikasi dan tanggungjawab, mempunyai inisiatif, kreatif, prinsip yang diyakini, memiliki tujuan jangka panjang serta kualitas pekerjaan.

Perilaku proaktif adalah jenis perilaku kerja yang termotivasi dengan pemikiran yang terbuka (Bateman \& Crant, 1993). Meskipun konsep perilaku proaktif didefinisikan secara berbeda, sebuah konsensus umum muncul di antara para peneliti pada perilaku proaktif seperti berpikiran terbuka dan berinisiatif untuk memecahkan masalah (Crant, 2000; Grant \& Ashford, 2008). Orang-orang dengan perilaku proaktif lebih cenderung mencari informasi dan membawa ide secara spontan ke arah perubahan besar di sekitarnya (Crant, 2000). Selanjutnya, dengan inisiatif mereka sendiri, karyawan proaktif maju untuk mengajukan ide bagi pemecahan masalah organisasi dan membuat upaya untuk mencegah munculnya kembali masalah serupa (Parker et al., 2006). Grant \& Ashford (2008) menggambarkan perbedaan antara perilaku proaktif dan perilaku termotivasi dan perilaku reaktif dalam dua aspek, seperti bertindak lebih dulu dan mampu memperkirakan konsekwensi yang terjadi. Menjadi karyawan yang proaktif berarti bertindak terlebih dahulu dengan lebih antisipatif dan penuh perhatian. Di sisi lain, dengan menjaga niat kuat untuk mengubah lingkungan, karyawan berkeinginan untuk membawa hasil yang lebih nyata. Perilaku proaktif diperlukan untuk mengubah diri sendiri, rekan-rekan mereka, atau lingkungan (Grant \& Ashford, 2008). Selain itu, perilaku proaktif mencakup perilaku antisipatif, penuh perencanaan, memecahkan masalah dan mencari cara untuk mengubah keadaan saat ini (Parker \& Collins, 2010; Parker et al., 2006).

\section{METODE}

Pada penelitian ini, metode penarikan sampel yang digunakan adalah sampel terpilih (purposive sampling) dengan kriteria karyawan tetap dengan masa kerja minimal satu tahun dan berlatar belakang pendidikan minimal SLTA. Sebanyak 700 karyawan yang bekerja di 37 hotel bintang dan non bintang di seluruh Indonesia menjadi sampel dalam penelitian ini. Mereka berasal dari seluruh departemen seperti : Front Office, Housekeeping, Man Power, Food \& Beverage, Accounting, dan Marketing.

Dalam penelitian ini data primer diperoleh dengan cara menyebarkan kuisioner melalui email kepada karyawan berdasarkan asumsi bahwa responden adalah orang yang paling tahu tentang keadaan dirinya, apa yang dinyatakan responden adalah benar dan dapat dipercaya dan interprestasi responden terhadap pertanyaan atau pernyataan yang diajukan adalah sama dengan apa yang dimaksud peneliti. Data sekunder diperoleh dari data mengenai sejarah berdirinya perusahaan, tujuan perusahaan, letak geografis, sumber daya manusia, struktur organisasi, tugas dan wewenang, sistem kompensasi, fasilitas yang tersedia, dan gambaran strategis perusahaan.

Dalam penelitian ini ada tiga macam data yang dikumpulkan yaitu : data tentang persepsi terhadap kompensasi, data tentang sikap proaktif dan data tentang motivasi kerja. Adapun pengukuran yang digunakan adalah skala peringkat sederhana dengan ukuran 1- 
10 dengan alasan skala yang memiliki lebih banyak poin memiliki kemampuan lebih baik dalam menunjukkan derajat perbedaan (diferensiasi) variabel. Pada umumnya orang memahami nilai 10 menunjukkan nilai terbaik atau sempurna (Sangat setuju), dan nilai 1 menunjukkan nilai terburuk (Sangat tidak setuju).

Skor persepsi terhadap kompensasi, sikap proaktif, dan motivasi kerja dicari dengan menghitung nilai rata-rata (mean) setelah menjumlahkan nilai keseluruhan jawaban dari setiap item pertanyaan pada masing-masing variabel. Pada penelitian ini, persepsi terhadap variabel kompensasi diukur berdasarkan penilaian responden terhadap sembilan pernyataan pada kuesioner mengenai gaji pokok, tunjangan, jaminan, promosi dan fasilitas yang diberikan perusahaan. Contoh pernyataan tersebut antara lain: "Kompensasi yang saya terima (uang, promosi, bonus, cuti dan lain-lain) sudah sesuai dengan pekerjaan saya" dan "Perusahaan memberi kesempatan kepada karyawan untuk mengembangkan karir."

Variabel sikap proaktif diukur berdasarkan dedikasi dan tanggungjawab pribadi, inisiatif-kreatif, prinsip yang dimiliki, kualitas pekerjaan dan pengetahuan akan tugas yang diemban melalui sembilan pernyataan pada kuesioner yang diantaranya adalah: "Saya tahu apa yang saya lakukan untuk meningkatkan kemampuan dan pengetahuan saya" dan "Saya tidak pernah ragu untuk mengambil suatu keputusan dengan tepat."

Sementara variabel motivasi kerja diukur berdasarkan penilaian karyawan terhadap keamanan dan keselamatan, kepemimpinan yang baik, rekan kerja yang sesuai dan kondisi kerja, upah yang layak, penghargaan atas prestasi pekerjaan dan kesempatan untuk maju melalui 10 pernyataan antara lain sebagai berikut: "Perusahaan memberikan jaminan keamanan dan keselamatan kerja" dan "Pimpinan saya telah menghargai bawahan sebagai pribadi manusia".

Ada tiga variabel dalam penelitian ini yaitu persepsi terhadap kompensasi $(X)$, motivasi kerja $(Y)$, dan sikap proaktif $(Z)$.
Penelitian ini memiliki hipotesis umum bahwa ada hubungan antara persepsi terhadap kompensasi dengan motivasi kerja. Semakin besar nilai positif persepsi karyawan terhadap kompensasi maka semakin tinggi motivasi kerja, tetapi penelitian ini juga ingin memeriksa apakah hubungan ini dipengaruhi oleh sikap proaktif. Dalam hal ini, jika dua variabel, $X \& Y$, berkorelasi dengan variabel ketiga yaitu $Z$ maka variabel $X$ dan $Y$ kemungkinan berkorelasi satu sama lain hanya karena keduanya terkait dengan variabel ketiga. Adalah menarik untuk mengetahui apakah ada korelasi antara $X$ dan $Y$ yang bukan karena keduanya berkorelasi dengan $Z$. Untuk melakukan ini diperlukan statistik korelasi parsial.

Penelitian ini mengasumsikan bahwa hubungan antara persepsi terhadap kompensasi dan motivasi kerja akan semakin kuat ketika karyawan memiliki sikap proaktif yang juga kuat. Motivasi kerja yang hanya berdasarkan dorongan insentif kompensasi cenderung tidak akan bertahan lama sedangkan sikap proaktif cenderung lebih permanen. Karena alasan ini, statistik penelitian ini menggunakan korelasi parsial untuk memeriksa apakah ada hubungan linear antara persepsi terhadap kompensasi dengan motivasi kerja dengan memperhitungkan sikap proaktif. Penelitian ini memiliki satu variabel dependen yaitu 'motivasi kerja' dan satu variabel independen yaitu 'persepsi terhadap kompensasi' sementara 'sikap proaktif' berfungsi sebagai variabel kontrol. Koefisien korelasi parsial dapat ditulis dalam bentuk koefisien korelasi sederhana sebagai berikut:

$$
r_{X Y . Z}=\frac{r_{X Y}-r_{X Z} r_{Y Z}}{\sqrt{\left(1-r_{X Z}^{2}\right)\left(1-r_{Y Z}^{2}\right)}}
$$

Pada penelitian ini, koefisien korelasi antara variabel $X$ dan $Y$ dan juga koefisien korelasi antara $X$ atau $Y$ dengan $Z$ dihitung dengan rumus Pearson Product Moment formula:

$$
\boldsymbol{r}_{x y}=\frac{N \sum X Y-\sum X \sum Y}{\sqrt{\left[N \sum X^{2}-\left(\sum X\right)^{2}\right]\left[N \sum Y^{2}-\left(\sum Y\right)^{2}\right]}} .
$$

Kedua rumus tersebut digunakan karena datanya bersifat kontinyu. Korelasi Pearson 
mengasumsikan bahwa variabel yang digunakan untuk menghitung koefisien korelasi harus berasal dari populasi normal sementara distribusi normal merupakan data kontinyu. Berikut ini adalah hipotesis nol dan penelitian:

Hipotesis nol: Tidak terdapat korelasi yang signifikan antara persepsi terhadap kompensasi dan motivasi kerja dengan kontrol terhadap sikap proaktif karyawan $\mathrm{Ho}$ : $\rho=0$

Hipotesis penelitian: Terdapat korelasi yang signifikan antara persepsi terhadap kompensasi dan motivasi kerja dengan kontrol terhadap sikap proaktif karyawan $H_{1}$ : $\rho \neq 0$

\section{HASIL DAN PEMBAHASAN Hasil}

Penelitian ini hendak menyelidiki apakah terdapat korelasi yang signifikan antara variabel independen yaitu persepsi terhadap kompensasi dan sikap proaktif karyawan dengan variabel dependen yaitu motivasi kerja. Hasil pengumpulan data deskriptif terhadap 700 karyawan yang bekerja di 37 hotel bintang dan non bintang di seluruh Indonesia yang menjadi sampel dalam penelitian ini disajikan dalam tabel distribusi frekuensi berikut yang terdiri dari tabel mengenai persepsi terhadap kompensasi, sikap proaktif dan motivasi kerja. Berdasarkan data tabel 1 diketahui bahwa sebanyak $70.7 \%$ responden menyatakan bahwa mereka memiliki pandangan yang sangat baik (sangat positif) hingga baik (positif) terhadap kompensasi yang mereka terima dari perusahaan (Skala 7-10); sebanyak $7 \%$ memiliki pandangan yang sangat negatif hingga negatif terhadap kompensasi yang mereka terima (Skala $1-4$ ) dan; sebanyak $22,3 \%$ menyatakan ragu-ragu (Skala 3-3.9).

Adapun sebanyak $85.6 \%$ responden menunjukkan sikap yang sangat proaktif hingga proaktif ketika bekerja (Skala 7-10); Sebanyak 5\% menunjukkan sikap yang sangat tidak proaktif hingga tidak proaktif (Skala 14) dan; sebanyak 9.3\% menunjukkan sikap ragu (Skala 5 - 6). Pada variabel motivasi kerja, sebanyak $70.6 \%$ responden menyatakan bahwa mereka memiliki motivasi yang sangat kuat hingga kuat (Skala 7-10) dalam melakukan pekerjaan mereka; sebanyak $6.7 \%$ menyatakan mereka tidak memiliki atau sangat tidak memiliki motivasi (Skala 1 - 4) dan; sebanyak $22.7 \%$ menyatakan ragu-ragu (Skala 5 -6). Nilai Cronbach's alphas untuk 9 pernyataan mengenai persepsi untuk kompensasi, 9 pernyataan untuk sikap proaktif dan 10 pernyataan mengenai motivasi kerja berturutturut adalah 0,$80 ; 0,78$, dan 0,72 .

Tabel 1. Prosentase dan skala jawaban responden terhadap kompensasi, sikap proaktif dan motivasi kerja $(\%)$

\begin{tabular}{cccc}
\hline Skala & $\begin{array}{c}\text { Persepsi } \\
\text { kompensasi }\end{array}$ & $\begin{array}{c}\text { Sikap } \\
\text { proaktif }\end{array}$ & $\begin{array}{c}\text { Motivasi } \\
\text { kerja }\end{array}$ \\
\hline $9-10$ & 12,0 & 37,3 & 19,3 \\
$7-8$ & 58,7 & 48,3 & 51,3 \\
$5-6$ & 22,3 & 9,3 & 22,7 \\
$3-4$ & 3,3 & 0,7 & 4,0 \\
$1-2$ & 3,7 & 4,3 & 2,7 \\
\hline total & 100,0 & 100,0 & 100,0 \\
\hline
\end{tabular}

Sumber : Data primer, 2017

Nilai rata-rata (mean) jawaban responden terhadap sembilan item pertanyaan variabel kompensasi dengan menggunakan skala peringkat sederhana (1-10) adalah 7,2 dengan deviasi baku 2,33 dan sebanyak 700 responden $(\mathrm{N}=700)$ memberikan jawaban; Nilai rata-rata jawaban responden terhadap 10 item pertanyaan variabel motivasi dengan menggunakan skala perin $1-10$ adalah 7,19 dengan deviasi baku 2,2 dan sebanyak 700 responden $(\mathrm{N}=700)$ memberikan jawaban; Nilai rata-rata jawaban responden terhadap sembilan item pertanyaan variabel proaktif dengan menggunakan skala peringkat sederhana adalah 6,75 dengan deviasi baku 2,39 dan sebanyak 700 responden memberikan jawaban (Tabel 2: Statistik Deskriptif). 
Tabel 2. Statistik Deskriptif

\begin{tabular}{|lccc|}
\hline & Mean & $\begin{array}{c}\text { Std. } \\
\text { Deviation }\end{array}$ & $\mathrm{N}$ \\
\hline Compensation & 7,2043 & 2,33460 & 700 \\
Motivation & 7,1986 & 2,21756 & 700 \\
Proactive & 6,7557 & 2,39851 & 700 \\
\hline
\end{tabular}

Sumber : Analisa data primer, 2017

Hasil analisa dengan menggunakan korelasi Pearson menunjukkan adanya hubungan yang signifikan antara variabel persepsi kompensasi dan sikap proaktif dengan motivasi kerja (Tabel 3). Persepsi kompensasi menunjukkan hubungan yang signifikan dengan dengan motivasi kerja $r$ $(698)=0,814, \mathrm{p}<.01$, signifikan 2-tailed . Persepsi kompensasi menunjukkan hubungan yang signifikan dengan dengan variabel sikap proaktif $r(698)=0,718$, dimana $\mathrm{p}<.01$, signifikan 2-tailed. Variabel sikap proaktif menunjukkan hubungan yang signifikan dengan dengan motivasi kerja $r(699)=0,715$, $p<.01$, signifikan 2-tailed;

Langkah selanjutnya adalah melakukan korelasi parsial antara variabel $X, Y$ dan $Z$. Dalam hal ini, ketika variabel kontrol $Z$ memiliki hubungan yang signifikan dengan $Y$ (variabel dependen) dan $\mathrm{X}$ (variabel independen) maka penggunaan korelasi parsial menjadi lebih tepat. Di bawah kondisi ini, korelasi murni relatif antara $\mathrm{X}$ dan $\mathrm{Y}$ bisa diperoleh, namun dengan efek $\mathrm{Z}$ dikendalikan (dibuat tetap). Namun, jikapun $\mathrm{Z}$ tidak memiliki korelasi yang signifikan dengan $X$ dan Y, koefisien korelasi parsial juga akan berubah tapi perubahan nilai ini kecil dan tidak berarti (Researchgate, 2014).

Dalam penelitian ini, kalkulasi statistik menunjukkan bahwa korelasi parsial variabel kompensasi dan motivasi kerja menunjukkan koefisien korelasi 0,617. Hal ini menunjukkan bahwa terjadi hubungan yang sedikit melemah antara variabel kompensasi dengan motivasi kerja dengan kontrol terhadap sikap proaktif dikendalikan (dibuat tetap). Sedangkan arah hubungan adalah positif karena nilai $r$ positif, artinya semakin tinggi nilai kompensasi maka semakin meningkatkan motivasi kerja. Hal ini berarti kekuatan korelasi kompensasi dan motivasi kerja berkurang atau sedikit melemah jika tidak disertai pengaruh variabel sikap proaktif. Namun demikian korelasi kompensasi dan motivasi kerja tetap kuat walaupun tanpa variabel sikap proaktif.

Berdasarkan hasil di atas maka dapat dikatakan bahwa terdapat korelasi yang signifikan antara persepsi terhadap kompensasi dan motivasi kerja jika nilai sikap proaktif karyawan dikontrol sehingga $H_{l}: \rho \neq$ 0 . Selanjutnya berdasarkan data ini maka hipotesa nol $\left(H_{o}\right)$ yang menyatakan bahwa tidak terdapat hubungan yang signifikan antara persepsi kompensasi dengan motivasi kerja dengan kontrol terhadap sikap proaktif dapat ditolak karena pada kenyataannya terdapat hubungan yang signifikan antara persepsi kompensasi dengan motivasi kerja. Begitu pula hipotesa yang menyatakan bahwa tidak terdapat hubungan yang signifikan antara sikap proaktif dengan motivasi kerja dapat ditolak karena pada kenyataanya terdapat terdapat hubungan yang signifikan antara sikap proaktif dengan motivasi kerja.

\begin{tabular}{|c|c|c|c|c|}
\hline $\begin{array}{c}\text { Control } \\
\text { Variables }\end{array}$ & & $\begin{array}{c}\text { Compensat } \\
\text { ion }\end{array}$ & $\begin{array}{c}\text { Motivati } \\
\text { on }\end{array}$ & $\begin{array}{l}\text { Proacti } \\
\text { ve }\end{array}$ \\
\hline \multirow{3}{*}{$\begin{array}{l}\text { Compensat } \\
\text { ion }\end{array}$} & Correlation & 1,000 & 0,814 & 0,718 \\
\hline & $\begin{array}{l}\text { Significanc } \\
\text { e (2-tailed) }\end{array}$ & & 0,000 & 0,000 \\
\hline & $\mathrm{df}$ & 0 & 698 & 698 \\
\hline \multirow{3}{*}{ Motivation } & Correlation & 0,814 & 1,000 & 0,715 \\
\hline & $\begin{array}{l}\text { Significanc } \\
\text { e (2-tailed) }\end{array}$ & 0,000 & & 0,000 \\
\hline & df & 698 & 0 & 698 \\
\hline \multirow{3}{*}{ Proactive } & Correlation & 0,718 & 0,715 & 1,000 \\
\hline & $\begin{array}{l}\text { Significanc } \\
\text { e (2-tailed) }\end{array}$ & 0,000 & 0,000 & \\
\hline & $\mathrm{df}$ & 698 & 698 & \\
\hline \multirow{3}{*}{$\begin{array}{l}\text { Compensat } \\
\text { ion }\end{array}$} & Correlation & 1,000 & 0,617 & \\
\hline & $\begin{array}{l}\text { Significanc } \\
\text { e (2-tailed) }\end{array}$ & & 0,000 & \\
\hline & $\mathrm{df}$ & 0 & 697 & \\
\hline \multirow[t]{2}{*}{ Proactive } & df & 0 & 697 & \\
\hline & Correlation & 0,617 & 1,000 & \\
\hline \multirow[t]{2}{*}{ Motivation } & $\begin{array}{l}\text { Significanc } \\
\text { e (2-tailed) }\end{array}$ & 0,000 & & \\
\hline & df & 697 & 0 & \\
\hline
\end{tabular}

Sumber: Olah data dgn SPSS, 2017 


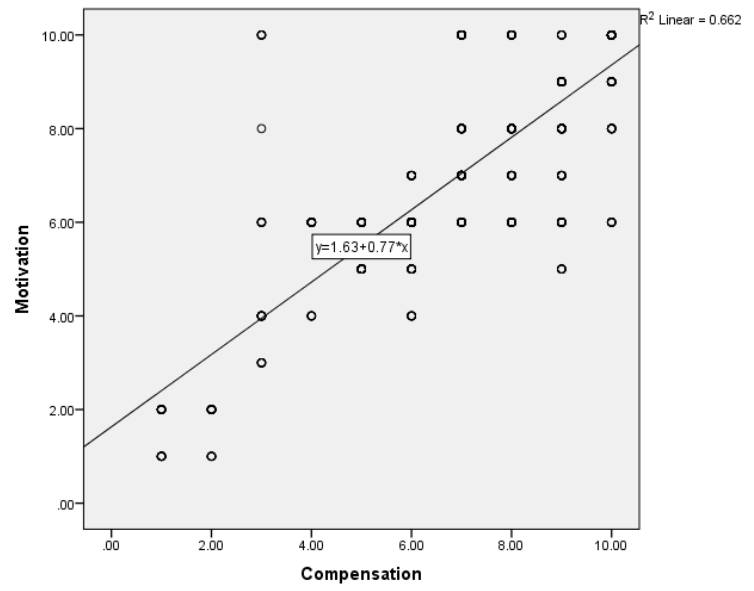

Gambar 1. Grafik Sebaran Nilai Kompensasi dan Motivasi.

Sumber: olah data SPSS, 2017

Gambar 1 menunjukkan sebaran nilai (scatter plot) korelasi langsung antara variabel independen persepsi terhadap kompensasi (variabel $X$ ) dan variabel dependen motivasi kerja (variabel $Y$ ) tanpa memasukkan variabel sikap proaktif (variabel $Z$ ) dan menghasilkan nilai $R^{2}$ linear 0.662 atau $66.2 \%$. Hal ini berarti $66.2 \%$ variasi dalam variabel dependen $Y$ dijelaskan oleh variabel independen $X$ yang ada dalam model ini.

Persamaan regresi linear yang ditunjukkan pada model ini adalah :

$$
Y=1,63+0.77 x
$$

Hal ini berarti tingkat motivasi kerja karyawan ditentukan oleh besar kompensasi yang diterimanya dikalikan dengan 0,77 ditambah dengan nilai konstanta 1,63.

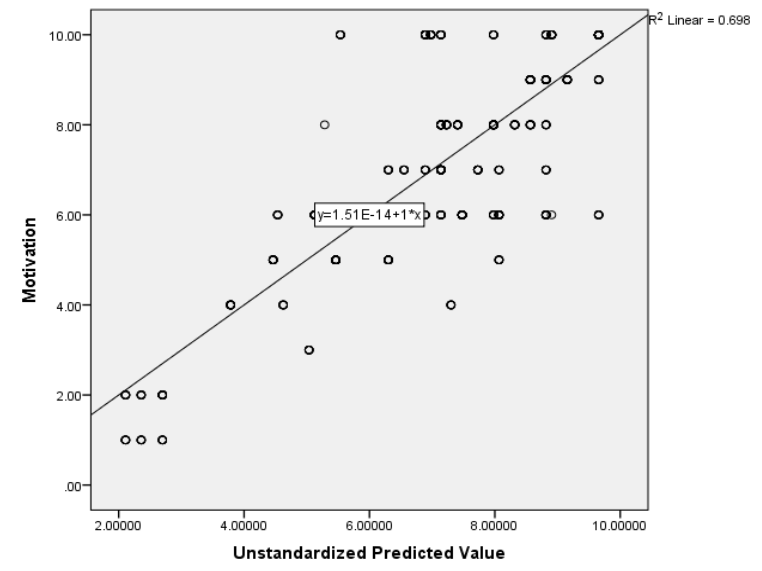

Gambar 2. Grafik Sebaran dua nilai Sumber: olah data SPSS, 2017
Gambar 2 menunjukkan grafik sebaran nilai (scatter plot) korelasi antara kombinasi dua nilai perkiraan variabel independen (unstandardized predicted value) yaitu persepsi terhadap kompensasi $\left(X_{l}\right)$ dan variabel sikap proaktif $\left(X_{2}\right)$ dengan variabel dependen motivasi kerja (variabel $Y$ ) yang menghasilkan nilai $R^{2}$ linear adalah 0.698 atau $69,8 \%$. Hal ini berarti $69,8 \%$ variasi dalam variabel dependen $Y$ dijelaskan oleh variabel independen $X$ yang ada dalam model ini. Hal ini menunjukkan bahwa hubungan antara variabel persepsi terhadap kompensasi dan sikap proaktif secara bersama-sama memberikan pengaruh yang lebih besar terhadap variabel motivasi kerja. Sekali lagi bahwa kekuatan korelasi kompensasi dan motivasi kerja berkurang atau sedikit melemah jika tidak disertai pengaruh variabel sikap proaktif. Namun demikian korelasi kompensasi dan motivasi kerja tetap kuat walaupun tanpa variabel sikap proaktif.

\section{Pembahasan}

Tujuan dari penelitian ini adalah untuk meningkatkan pemahaman mengenai persepsi terhadap kompensasi terhadap motivasi kerja dengan kontrol pada perilaku kerja proaktif. Lebih khusus lagi, untuk menguji apakah hubungan positif antara persepsi terhadap kompensasi masih tetap berperan penting terhadap motivasi kerja karyawan dalam hal karyawan tidak memiliki perilaku kerja proaktif. Hasil penelitian menunjukkan hal itu memang demikian adanya, bahwa kompensasi tetap berperan penting dalam mendorong motivasi kerja.

Kompensasi mempunyai pengaruh positif terhadap motivasi. Manusia bekerja untuk dapat memenuhi kebutuhan hidupnya sehari-hari. Apabila perusahaan menginginkan karyawannya termotivasi dalam menjalankan pekerjaan, maka perusahaan harus berusaha untuk memenuhi kebutuhan para karyawannya. Kompensasi yang diberikan kepada karyawan sangat berpengaruh terhadap motivasi kerja karena berbagai macam bentuk kompensasi berfungsi untuk memotivasi karyawan agar produktivitasnya lebih tinggi. 
Kompensasi juga mempunyai pengaruh positif terhadap kinerja, dan dengan dijalankannya sistem pemberian kompensasi yang baik dan adil, maka diharapkan dapat mendorong karyawan untuk meningkatkan kinerjanya. Dengan demikian karyawan akan berusaha untuk meningkatkan kinerjanya karena semakin bagus kinerja maka karyawan tersebut akan memperoleh imbalan kompensasi yang lebih baik dibandingkan dengan karyawan lain.

Hasil penelitian ini secara umum menunjukkan hasil yang lebih kurang sama dengan studi sebelumnya. Misalnya, studi oleh Ghazanfar et.al. (2011) yang menemukan bahwa kepuasan terhadap kompensasi yang diterima dapat menjadi faktor motivasi kerja. Begitu pula studi yang dilakukan Mensah dan Tawiah (2016) tentang motivasi karyawan dan kinerja kerja menemukan bahwa pihak manajemen harus memastikan bahwa karyawan termotivasi dengan baik agar mereka tidak melakukan pemogokan dan kerusuhan industri yang mempengaruhi kinerja mereka. Studi lain oleh Ghafari et. Al. (2017) menunjukkan bahwa sikap proaktif yang paling signifikan untuk mendukung kinerja pekerjaan karyawan adalah rasa tanggung jawab. Jehanzeb et.al (2012) menemukan bahwa karyawan di sektor perbankan lebih mementingkan imbalan ekonomi atau keuangan. Jadi, jika imbalan ditingkatkan, maka motivasi kerja karyawan yang bekerja pada bank publik dan swasta juga meningkat.

Hasil penelitian ini juga sejalan dengan studi yang dilakukan Bakan \& Buyukbese (2013) yang menunjukkan hubungan yang signifikan antara tingkat pendapatan karyawan dan kepuasan kerja karyawan. Ling et.al. (2017) juga menunjukkan terjadinya efek mediasi parsial pada perilaku proaktif dalam hubungan antara kualitas pekerjaan (quality of work life) dan kesuksesan karir. Ling menemukan bahwa kualitas kerja dapat secara positif mempengaruhi kesuksesan karir (motivasi) di kalangan akademisi jika mereka memiliki perilaku proaktif dan bersemangat untuk mencapai tingkat keberhasilan karir yang lebih tinggi.
Kompensasi memiliki hubungan erat dengan kebutuhan hidup yang menjadi salah satu alasan bagi individu untuk lebih giat dan aktif bekerja, dan untuk mencapai hal ini diperlukan adanya motivasi dalam melakukan pekerjaan. Selain itu, motivasi mempunyai pengaruh positif terhadap kinerja. Motivasi dapat mendorong seseorang bekerja lebih keras dan selalu berkeinginan untuk melanjutkan usahanya. Oleh karena itu karyawan yang mempunyai motivasi kerja tinggi biasanya mempunyai kinerja yang tinggi pula.

Individu proaktif melibatkan perilaku yang penuh inisiatif (self-initiated), berorientasi masa depan, dan berorientasi perubahan (Frese \& Fay, 2001; Parker et al., 2006). Individu proaktif mampu merancang dan menerapkan metode kerja baru atau secara aktif mencari umpan balik dari supervisor. Hasil penelitian ini menegaskan bahwa perilaku proaktif merupakan perilaku positif yang dapat mengarah pada peningkatan kinerja dan efektivitas individu dan organisasi, terutama ketika karyawan diminta untuk menanggapi perubahan kondisi dan tuntutan kerja (Griffin et al., 2007).

Dalam penelitian ini perlu pula dikemukakan beberapa batasan dan juga rekomendasi bagi penelitian lebih lanjut. Keterbatasan utama penelitian ini adalah penggunaan penilaian oleh diri sendiri atau laporan diri (self-rating measures) untuk mengukur ketiga variabel penelitian. Teknik ini bisa jadi menjadi cara terbaik untuk mengukur variabel persepsi terhadap kompensasi tetapi bisa jadi kurang reliable untuk motivasi kerja terlebih lagi perilaku proaktif. Hal ini menimbulkan potensi overestimasi hubungan antara variabel karena bias yang berasal dari diri responden dalam mengukur dirinya (Podsakoff et al., 2003). Jika pengukuran oleh diri sendiri tampaknya menjadi cara terbaik untuk mengukur persepsi terhadap kompensasi, studi masa depan mungkin perlu memasukkan teknik pengukuran lain untuk menilai variabel sikap proaktif dan motivasi kerja dengan menggunakan data yang lebih obyektif, misalnya pengukuran oleh rekan kerja. 
Namun, sebagaimana yang direkomendasikan oleh Podsakoff et al. (2003), jawaban yang diberikan responden dalam studi ini adalah anonim sehingga karyawan merasa bebas mengemukakan panilaiannya tanpa ada beban diketahui atasan dan juga penelitian ini menggunakan item pernyataan yang menggambarkan sikap proaktif dan motivasi kerja dengan cara yang sangat konkret. Oleh karena itu, bias diharapkan dapat diminimalisir.

Model konseptual yang digunakan dalam studi ini secara implisit berpandangan bahwa kompensasi berfungsi sebagai prediktor motivasi kerja yang dimediasi oleh perilaku proaktif. Asumsi ini dibangun berdasarkan model perilaku proaktif sebelumnya yang didasarkan pada data longitudinal (Parker et al., 2006; Grant \& Ashford, 2008). Selain itu, literatur model karakteristik pekerjaan juga mendukung beberapa variabel lainnya, misalnya lingkungan kerja, sebagai prediktor untuk perilaku yang berhubungan dengan pekerjaan (Humphrey et al., 2007). Namun demikian, kita juga dapat membayangkan jalur sebab-akibat terbalik: Karyawan menjadi proaktif, mengambil lebih banyak tugas dan menciptakan lebih banyak tekanan untuk diri mereka sendiri, yang dipengaruhi motivasi kerja dan penghasilan mereka yang tinggi. Fay dkk. (1998) telah menguji hubungan timbal balik antara tekanan waktu dan perilaku proaktif dan menemukan efek positif dari tekanan waktu pada perilaku proaktif tetapi tidak ada efek perilaku proaktif pada tekanan waktu. Penelitian selanjutnya juga harus mempertimbangkan desain riset longitudinal (misalnya, selama beberapa hari, minggu, atau tahun) yang berfokus pada proses intra-individual antara motivasi kerja dan perilaku proaktif.

Hasil penelitian ini juga mendukung penelitian sebelumnya yang menunjukkan pentingnya tujuan dan emosi untuk meningkatkan fungsi dan kinerja karyawan (Ashforth, et al., 2007; Ryan \& Deci, 2000). Dari perspektif ini, disarankan untuk memperkuat penelitian tentang hubungan antara kepribadian dan perilaku proaktif karena studi di masa lalu hampir secara eksklusif berfokus pada kepribadian proaktif (Bateman \& Crant, 1993; Fuller \& Marler, 2009). Studi terbaru, misalnya oleh (Wu \& Parker, 2012a) menyoroti bahwa kepribadian proaktif tidak lagi cukup untuk menjelaskan mengapa beberapa orang, tetapi tidak yang lain, terlibat dalam perilaku proaktif. Hal ini juga tidak menjelaskan mengapa seseorang terlibat dalam perilaku proaktif pada satu kesempatan tetapi tidak yang lain.

Dengan demikian, direkomendasikan pula untuk mendorong studi masa depan yang berfokus pada faktor disposisional di luar kepribadian proaktif, termasuk studi yang menggambarkan mekanisme di mana kepribadian memberikan dampaknya, dan juga studi yang mempertimbangkan efek interaksi dengan faktor situasional. Direkomendasikan pula untuk membawa perspektif multilevel untuk mempelajari bagaimana faktor disposisional akan mempengaruhi perilaku proaktif pada konteks inter dan intra-individu.

\section{Kesimpulan}

Hasil penelitian menunjukkan bahwa terdapat hubungan yang kuat antara variabel kompensasi dan sikap proaktif dengan motivasi kerja. Persepsi kompensasi menunjukkan hubungan yang signifikan dengan dengan motivasi kerja dan persepsi kompensasi menunjukkan hubungan yang signifikan dengan variabel sikap proaktif serta variabel sikap proaktif menunjukkan hubungan yang signifikan dengan motivasi kerja. Hasil analisis korelasi parsial menunjukkan bahwa hubungan yang terjadi antara variabel kompensasi dengan motivasi kerja sedikit melemah jika sikap proaktif dikendalikan. Hasil penelitian ini menunjukkan bahwa kekuatan korelasi kompensasi dan motivasi kerja berkurang atau sedikit melemah jika tidak disertai pengaruh variabel sikap proaktif. Namun demikian korelasi kompensasi dan motivasi kerja tetap kuat walaupun tanpa variabel sikap proaktif.

Hasil penelitian juga menunjukkan bahwa terdapat korelasi yang signifikan antara persepsi terhadap kompensasi dan 
motivasi kerja jika nilai sikap proaktif karyawan dikontrol.

\section{DAFTAR PUSTAKA}

Arefin, Md. Shamsul, Ishtiaque Arif \& Muhammad Raquib (2015). HighPerformance Work Systems and Proactive Behavior: The Mediating Role of Psychological Empowerment. International Journal of Business and Management; Vol. 10, No. 3. pp 132-140.

Ashforth, Blake E. Ashforth, David M. Sluss, Alan M. Saks (2007). Socialization tactics, proactive behavior, and newcomer learning: Integrating socialization models. Journal of Vocational Behavior 70 (2007) 447-462

Azwar, Saifudin (2000). Sikap Manusia ; Teori dan Pengukurannya, edisi ke-2, Pustaka Pelajar, Yogyakarta.

Bakan, Ismail \& Buyukbese, Tuba (2013). The Relationship between Employees' Income Level and Employee Job Satisfaction: An Empirical Study. International Journal of Business and Social Science Vol. 4 No. 7; pp 18-25.

Barnes, M.C; A.H. Fogg; C.N. Stephens; dan L.G. Titman (1988). Organisasi Perusahaan : Teori dan Praktek, alih bahasa oleh Bambang Kussriyanto, LPPM, Jakarta.

Barnett, B. R., \& Bradley, L. (2007). The impact of organizational support for career development on career satisfaction. Career Development International, 12(7), 617 636.

Bateman, T. S., \& Crant, J. M. (1993). The proactive component of organizational behavior: A measure and correlates. Journal of Organizational Behavior, 14(2), 103-118. http://dx.doi.org/10.1002/job. 4030140202

Bateman, T. S., \& Crant, J. M. (1993). The proactive component of organizational behavior: A measure and correlates. Journal of Organizational Behavior, 14(2), 103-118.

Besser, Terry L (1995) Reward and Organizational Goal Achievement : A Case Study of Toyota Motor
Manufacturing in Kentucky, Journal of Management.

Bremer, S.N. (1993) 366 Esai untuk Memotivasi Diri, alih bahasa Frans Kowa, Pustaka Binaman Pressindo, Jakarta.

Covey, Stephen R. (1998). The seven habits of highly effective people, alih bahasa oleh Budijanto, proofreader Lyndon Saputra, Binarupa aksara, Jakarta.

Crant, J. M. (2000). Proactive behavior in organizations. Journal of Management, 26(3), 435-462. http://dx.doi.org/10.1177/ 014920630002600304

Dessler, Gary (1995). Personnel Management $3^{\text {rd }}$ Edition, alih bahasa oleh Agus Darma, Erlangga, Jakarta.

Dwiatmika (1996) Faktor Kepercayaan Diri dan Proaktif dalam pengaruhnya Terhadap Kinerja Karyawan di PT United Traktor, Skripsi (tidak diterbitkan), Fakultas Psikologi UGM, Yogyakarta.

Emory, William C.; and Donald R. Cooper (1991). Business Research Methods, fourth edition, Boston Richard D. Irwin, INC.

Fay, Scott; Hurst, Erik and White, Michelle J (1998). "The Bankruptcy Decision: The Roles of Financial Benefit and Stigma." Working paper, University of Michigan.

Flippo, Edwin B (1993). Personnel Management ; Sixth Edition, alih bahasa Moh. Masud, Erlangga, Jakarta.

Frese, M., \& Fay, D. (2001). Personal initiative (PI): An active performance concept for work in the 21st century. In B. M. Staw \& R. M. Sutton (Eds.), Research in Organizational Behavior (Vol. 23, pp. 133-187). Amsterdam: Elsevier Science.

Fuller, B., JR., \& Marler, L. E. (2009). Change driven by nature: A meta-analytic review of the proactive personality literature. Journal of Vocational Behavior, 75, 329-345.

Ghaffari, Sara., Ishak Mad Shah., John Burgoyne., Mohammad Nazri., Jalal Rezk Salleh (2017) The Influence of Motivation on Job Performance: A Case Study at Universiti Teknologi Malaysia. Australian Journal of Basic and Applied Sciences, 11(4) March 2017, Pages: 92-99. 
Https://www.researchgate.net/profile/Sara _Ghaffari2/publication/315116839_The_I nfluence_of_Motivation_on_Job_Perform ance_A_Case_Study_at_Universiti_Tekn ologi_Malaysia/links/5915864c0f7e9b70f 49cf771/The-Influence-of-Motivation-onJob-Performance-A-Case-Study-atUniversiti-Teknologi-Malaysia.pdf

Ghazanfar, Faheem., Shuai Chuanmin, Muhammad Mahroof Khan \& Mohsin Bashir (2011). A Study of Relationship between Satisfaction with Compensation and Work Motivation. International Journal of Business and Social Science Vol. 2 No. 1; January 2011 Https://pdfs.semanticscholar.org/9b66/5e9 9595bd24b53b7b391dc27fbe9b45ca7b2.p df

Gibson, E. J. (1997). An ecological psychologist's prolegomena for perceptual development: A functional approach. In C. Dent-Read \& P. Zukow-Goldring (Eds.), Evolving explanations of development: Ecological approaches to organismenvironment systems (pp. 23-45). Washington, DC: American Psychological Association.

Gibson, James L; John M. Ivancevich; dan James H. Donnelly, Jr (1997) Organizations; behavior, structure and processes, ninth edition, Irwin.

Grant, A. M., \& Ashford, S. J. (2008). The dynamics of proactivity at work. In L. L. Cummings \& B. M. Staw (Eds.), Research in Organizational Behavior (Vol. 28, pp. 3-34). Greenwich, CT: JAI.

Greenberg, Jerald; dan Robert A. Baron (1997). Behavior in Organizations; understanding and managing the human side of work, sixth edition, Prentice-hall international, INC.

Griffin, M. A., Neal, A., \& Parker, S. K. (2007). A new model of work role performance: Positive behavior in uncertain and interdependent contexts. Academy of Management Journal, 50(2), 327-347.

Http://ijbssnet.com/journals/Vol_4_No_7 _July_2013/3.pdf.

Https://pdfs.semanticscholar.org/18b8/eb1 b94af18401e4610673e3f8bd6120f38fc.pd f

Hasibuan, Malayu (1990). Manajemen Sumber Daya Manusia, Mas Agung, Jakarta.

Herzberg, Frederick (1966). Work and the Nature of Man. Cleveland: World Publishing. OCLC 243610.

Herzberg, Frederick (January-February 1964). "The Motivation-Hygiene Concept and Problems of Manpower". Personnel Administrator (27): 3-7.

Jakarta Hotel Association (2017). Aneka Tantangan di Industri Perhotelan Zaman Now. DetikTravel. Https://travel. detik.com/travel-news/d-3725365/anekatantangan-di-industri-perhotelan-zamannow

Jehanzeb, Khawaja., Mazen F. Rasheed., Anwar Rasheed., Alamzeb Aamir (2012). Impact of Rewards and Motivation on Job Satisfaction in Banking Sector of Saudi Arabia. International Journal of Business and Social Science Vol. 3 No. 21; November 2012 Http://www.ijbssnet.com/ journals/Vol_3_No_21_November_2012/ 29.pdf

Kertonegoro, Sentanoe (1997). Perilaku di tempat kerja,YTKI, Jakarta.

Ling, Nyuk-Ping., Nur Fatihah Abdullah Bandar., Farida Abdul Halim., Agatha Lamentan Muda (2017). Proactive behaviour as a mediator in the relationship between quality of work life and career success. International Journal of Business and Society, Vol. 18 S4, 2017, 701-709

Luthans, Fred (1998) Organizational Behavior, eight edition, McGraw-Hill.

Martoyo, Susilo (1994) Manajemen Sumber Daya Manusia, Edisi 3, BPFE, Yogyakarta.

Mensah, Elizabeth Boye \& Tawiah, Kwesi Amponsah (2016). Employee Motivation and Work Performance: A Comparative Study of Mining Companies in Ghana. Journal of Industrial Engineering and Management Vol 9 No 2.

Miner, J.B., Ebrahimi, B., \& Wachtel, J.M. (1995). How deficiency in management contributes to the United States' 
competiveness problem and what can be done about it? Human Resource Management. Fall, p. 363.

Nayoan, Alexander (November 13, 2017). Aneka Tantangan di Industri Perhotelan Zaman Now. DetikTravel. Jakarta Hotel Association.

Https://travel.detik.com/travel-news/d3725366/aneka-tantangan-di-industriperhotelan-zaman-now

Parker, S. K., \& Collins, C. G. (2010). Taking stock: Integrating and differentiating multiple proactive behaviors. Journal of Management, 36(3), 633-662. Http://dx.doi.org/10.1177/0149206308321 554

Parker, S. K., Williams, H. M., \& Turner, N. (2006). Modeling the antecedents of proactive behavior at work. Journal of Applied Psychology, 91(3), 636-652. Http://dx.doi.org/10.1037/00219010.91.3.636

Pedler, Mike; John Burgoyne; dan Tom Boydell (1997). Kiat Mengembangkan Diri: Pedoman Praktis Menuju Sukses, alih bahasa oleh Faisal Mustafa, LPPM, Jakarta. Revisi, LP3S, Jakarta.

Peretomode, V. F. (1991). Educational Administration: Applied Concepts and Theoretical Perspective. Lagos: Joja Educational Research and Publishers.

PHRI (Indonesian Hotel and Restaurant Association) (2017). Aneka Tantangan di Industri Perhotelan Zaman Now. DetikTravel.

Https://travel.detik.com/travel-news/d3725365/aneka-tantangan-di-industriperhotelan-zaman-now

Podsakoff, P. M., MacKenzie, S. B., Lee, J. Y., \& Podsakoff, N. P. (2003). Common method biases in behavioral research: A critical review of the literature and recommended remedies. Journal of Applied Psychology, 88, 879-903.

Researchgate (2014). How to choose control variables in partial correlation analysis?

Https://www.researchgate.net/post/How_t o_choose_control_variables_in_partial_co rrelation_analysis
Ryan, R. M. and Deci, E. L. (2000). Intrinsic and extrin- sic motivations: Classic definitions and new directions. Contemporary Educational Psychology, 25:54-67.

Sagir, Soeharsono (1985). Motivasi dan Disiplin Kerja karyawan untuk meningkatkan produktivitas dan produksi, Seri Produktivitas II, LSIUP.

Skinner, B.F. (1953). Science and human nature. NewYork: Macmillan. In O. Austin Omomia \& T. A. Omomia (2014). Relevance of Skinner's Theory of Reinforcement on Effective School Evaluaution and Management. European Journal of Psychological Studies, 2014, Vol.(4), No 4 pp 174-180

Soekamdani, Hariyadi (November 13, 2017). Aneka Tantangan di Industri Perhotelan Zaman Now. DetikTravel. Perhimpunan Hotel \& Restoran Indonesia (PHRI). Https://travel.detik.com/travel-news/d3725365/aneka-tantangan-di-industriperhotelan-zaman-now

Wu, C. H., \& Parker, S. K. (2012a). The role of attachment styles in shaping proactive behaviour: An intra-individual analysis. Journal of Occupational and Organizational Psychology, 85, 523-530. 